\title{
BMJ Open Association between visceral obesity and hepatitis $C$ infection stratified by gender: a cross-sectional study in Taiwan
}

\author{
Yu-Chung Tsao, ${ }^{1,2,3,4}$ Jau-Yuan Chen,, ${ }^{3,4}$ Wei-Chung Yeh,, ${ }^{3,4}$ Yun-Shing Peng, ${ }^{4,5}$ \\ Wen-Cheng $\mathrm{Li}^{6,7}$
}

To cite: Tsao Y-C, Chen J-Y, Yeh W-C, et al. Association between visceral obesity and hepatitis $C$ infection stratified by gender: a cross-sectional study in Taiwan. BMJ Open 2017;0:e017117. doi:10.1136/ bmjopen-2017-017117

- Prepublication history for this paper is available online. To view please visit the journal online (http://dx.doi.org/10. 1136/bmjopen-2017-017117).

Received 4 April 2017

Revised 4 July 2017

Accepted 10 August 2017

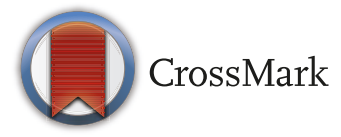

${ }^{1}$ Department of Occupational Medicine, Chang Gung Memorial Hospital, Linkou, Taoyuan,

Taiwan

${ }^{2}$ Department of Occupational

Medicine, Chang Gung Memorial

Hospital, Chiayi, Taiwan

${ }^{3}$ Department of Family Medicine, Chang Gung Memorial Hospital,

Linkou, Taoyuan, Taiwan

${ }^{4}$ College of Medicine, Chang Gung University, Taoyuan,

Taiwan

${ }^{5}$ Division of Endocrinology and Metabolism, Department of Internal Medicine, Chang Gung Memorial Hospital, Chiayi,

Taiwan

${ }^{6}$ Department of Emergency Medicine, Chang Gung Memorial Hospital, Linkou, Taoyuan,

Taiwan

${ }^{7}$ Department of Health

Management, Xiamen ChangGung Hospital, Xiamen, China

Correspondence to

Dr Wen-Cheng Li;

win3135@hotmail.com

\section{ABSTRACT}

Objectives The global prevalence of hepatitis $\mathrm{C}$ virus (HCV) is approximately $2 \%-3 \%$, and the prevalence of the positive anti-HCV antibody has been increasing. Several studies have evaluated regional adipose tissue distribution and metabolism over the past decades. However, no study has focused on the gender difference in visceral obesity among patients with HCV infection.

Design Retrospective cross-sectional study.

Setting We reviewed the medical records of patients who visited a hospital in Southern Taiwan for health check-up from 2013 to 2015.

Participants A total of 1267 medical records were collected. We compared patient characteristics, variables related to metabolic risk and body composition measured using bioelectrical impedance analysis between the groups. Regression models were built to adjust for possible confounding factors.

Results The prevalence rate of the positive anti-HCV antibody was $8.8 \%$ in the study population, $8.5 \%$ in men and $9.2 \%$ in women. Men with HCV infection tended to be older and have lower total cholesterol levels and higher alanine aminotransferase (ALT) levels $(p<0.001)$. Women with HCV infection tended to be older and have higher levels of fasting glucose and ALT $(p<0.001)$. After adjusting for confounding factors, body fat percentage, fat-free mass/body weight (BW) and muscle mass/BW were found to be the independent determinants of visceral obesity in patients without HCV infection $(p<0.001)$. However, the trend was not such obvious in patients with HCV infection, though still statistically significant $(p<0.05)$. Furthermore, the trend was less significant in men with HCV infection. Conclusions The findings suggested that HCV modulates host lipid metabolism and distribution to some extent, and a gender difference was also noted.

\section{INTRODUCTION}

The global prevalence of human hepatitis $\mathrm{C}$ virus (HCV) is approximately $2 \%-3 \%$, and the prevalence of the positive anti-HCV antibody increased from $2.3 \%$ to $2.8 \%$ between 1990 and 2005. ${ }^{1}$ HCV infection leads to chronic hepatitis in $60 \%-80 \%$ of infected individuals, ${ }^{2}$ and it is associated with liver

\section{Strengths and limitations of this study}

- Hepatitis C virus (HCV) infection is endemic to Taiwan, and we designed the study to determine the association between known metabolic factors and visceral obesity stratified by gender and HCV infection status.

- To our knowledge, there was no previous study focusing on the gender difference in visceral obesity among patients with HCV infection.

- In all participants, body fat percentage, visceral fat area, fat-free mass and muscle mass were measured using bioelectrical impedance analysis

- Because this cross-sectional study was retrospective, we did not have data on HCV RNA, antiviral treatment status, HCV genotype and detailed personal history, which may result in overestimation of and a lack of risk factors for lipid metabolism.

- The current result might only present the trend of the selected population.

steatosis, fibrosis, cirrhosis and hepatocellular carcinoma. ${ }^{3}$ According to data from the Liver Disease Prevention and Treatment Research Foundation, HCV prevalence in Taiwan has been estimated to be $4.4 \%$ in adults aged more than 20 years, with significant geographical variation. ${ }^{4}$

Abnormal fat accumulation in the liver (steatosis) is commonly observed in patients with HCV infection. ${ }^{5}$ The two main types of steatosis in patients with HCV infection are metabolic steatosis and viral steatosis. ${ }^{6}$ Metabolic steatosis is found in patients infected with genotype 1 and is associated with metabolic syndrome. By contrast, viral steatosis is reported in patients infected with genotype 3 a but without other known steatogenic cofactors, and this type of steatosis is directly linked to the cytopathic effect of the virus. Similarly, chronic HCV infection can also induce insulin resistance. ${ }^{7}$ 
Previous study indicated that HCV virus might resist antiviral treatment and promote fibrosis due to increased efficiency of viral replication by lipid accumulation in cells. ${ }^{8}$ Visceral obesity, which can be estimated by measuring waist circumference, and genotype 3a play roles in the development of steatosis. ${ }^{9}$ A previous study measured visceral obesity by using abdominal CT and indicated that HCV infection is a risk factor for the development of insulin resistance, particularly in patients with visceral obesity. ${ }^{10}$

Several studies have focused on regional adipose tissue distribution over recent decades, suggesting that the extent of visceral adipose tissue (VAT) accumulation may play an important role of the increased health risk in overweight and obesity. Variations in VAT accumulation across age, gender and ethnicity have also been extensively studied. ${ }^{11}$ However, no study has focused on the gender difference in visceral obesity among patients with HCV infection.

In the current study, we compared biochemical data and body composition between patients with positive and negative anti-HCV antibodies. Furthermore, we examined whether significant differences exist in body composition, particularly fat accumulation, between male and female patients with HCV infection.

\section{MATERIALS AND METHODS}

In this retrospective study, we reviewed the medical records of patients who visited Chiayi Chang Gung Memorial Hospital for self-paid health examination from May 2013 to December 2015. We collected their basic information including age, gender, body height $(\mathrm{cm})$, body weight $(\mathrm{BW} ; \mathrm{kg})$, waist circumference $(\mathrm{cm})$ and blood pressure (mm Hg). Body mass index (BMI) was calculated as the BW in kilograms divided by the square of the height in meters $\left(\mathrm{kg} / \mathrm{m}^{2}\right)$.

Fasting venous blood samples were collected from the patients to record biochemical data, including alanine aminotransferase (ALT; U/L), fasting plasma glucose $(\mathrm{mg} / \mathrm{dL})$, total cholesterol (TC; $\mathrm{mg} / \mathrm{dL}$ ), high-density lipoprotein (HDL; mg/dL) and triglyceride (TG; mg/ $\mathrm{dL}$ ). These parameters were determined using enzymatic, spectrophotometric and colorimetric methods. Anti-HCV antibody titre was determined using the electrochemiluminescence immunoassay.

We also recorded data of body fat percentage, visceral fat area, fat-free mass and muscle mass. These data were measured using bioelectrical impedance analysis (BIA) on a portable stand-on analyser model IOI-353 (Jawon Medical, Korea). Visceral obesity was defined as a visceral fat area $\geq 100 \mathrm{~cm}^{2}$, as described previously. ${ }^{12} 13$

We compared patient characteristics, variables related to the metabolic risk and body composition between groups (ie, male vs female and HCV vs non-HCV stratified by gender) by using an independent sample t-test. Because several t-tests were performed for multiple comparisons, we decreased the alpha level using the Bonferroni adjustment method. For example, the alpha level was set at $0.0028(0.05 / 18)$ for 18 tests. A series of univariate logistic regression analyses were performed to investigate the factors associated with visceral obesity in the wholestudy population and in patients with $\mathrm{HCV}$ infection. To study the risk factors for visceral obesity in the study population, we conducted multivariable logistic regression analysis using a backward elimination method. To assess the associations between body composition parameters (including body fat percentage, fat-free mass/BW and muscle mass/BW) and the risk of visceral obesity, we built several logistic regression models in which those body composition parameters were treated as explanatory variables. With consideration of our limited sample size (especially in the HCV-infective group, only 59 events in men and 13 events in women), it was not appropriate to adjust for multiple confounding factors then we may avoid the overfitting problem. Therefore, after a formal statistical testing termed as likelihood ratio test, we found only age significantly improved the model fit in men and women with HIV infection. Therefore, we evaluated these associations in the presence of adjusting for age (model 2) in both HCV-infective and non-HCV-infective population. Data analysis was conducted using SPSS V.22 (IBM SPSS, Armonk, NY: IBM Corp).

\section{RESULTS}

\section{Patient characteristics stratified by gender}

Table 1 shows the patient characteristics stratified by gender. The prevalence rate of the positive anti-HCV antibody was $8.8 \%$ in the study population, $8.5 \%$ in men and $9.2 \%$ in women $(\mathrm{p}=0.672)$. The mean age was similar in men and women $(\mathrm{p}=0.268)$. Men had significantly higher BMI, waist circumference, waist to height ratio and systolic and diastolic blood pressure $(\mathrm{p}<0.001)$. Regarding biochemical data, men had higher levels of fasting glucose, ALT and TG but lower levels of TC and HDL $(p<0.001)$. Moreover, men tended to have higher fat-free mass, muscle mass, visceral fat area and prevalence of visceral obesity but lower body fat percentage $(\mathrm{p}<0.001)$.

\section{Patient characteristics stratified by HCV}

Compared with the men without HCV infection, the men with HCV infection tended to be older and have lower TC levels and higher ALT levels $(\mathrm{p}<0.001)$. Waist circumstance, waist to height ratio, fasting glucose level and visceral obesity rate were similar between the two groups (table 2).

Compared with the women without HCV infection, the women with HCV infection tended to be older and have higher fasting glucose and ALT levels $(\mathrm{p}<0.001)$. Moreover, the women with HCV infection had higher body fat, visceral fat area and prevalence of visceral obesity, although the results were not statistically significant after adjusting for multiple confounding factors (table 2). 
Table 1 Summary of patient characteristics stratified by gender

\begin{tabular}{|c|c|c|c|}
\hline Variable & $\begin{array}{l}\text { Male } \\
(n=777)\end{array}$ & $\begin{array}{l}\text { Female } \\
(n=490)\end{array}$ & p Value \\
\hline Age (year) & $54.7(12.2)$ & $53.9(11.2)$ & 0.268 \\
\hline BMI $\left(\mathrm{kg} / \mathrm{m}^{2}\right)$ & $25.3(3.4)$ & $23.4(3.5)$ & $<0.001^{*}$ \\
\hline $\begin{array}{l}\text { Waist circumstance } \\
(\mathrm{cm})\end{array}$ & $87.3(9.0)$ & $76.5(8.8)$ & $<0.001^{*}$ \\
\hline Waist to height ratio & $0.52(0.05)$ & $0.49(0.06)$ & $<0.001^{*}$ \\
\hline SBP $(\mathrm{mm} \mathrm{Hg})$ & $128.8(19.4)$ & $123.1(23.0)$ & $<0.001^{*}$ \\
\hline DBP (mm Hg) & 74.9 (11.9) & $67.5(11.6)$ & $<0.001^{\star}$ \\
\hline MAP $(\mathrm{mm} \mathrm{Hg})$ & $92.9(13.4)$ & $86.0(14.3)$ & $<0.001^{\star}$ \\
\hline $\begin{array}{l}\text { Fasting glucose } \\
(\mathrm{mg} / \mathrm{dL})\end{array}$ & $109.1(31.8)$ & $101.9(27.1)$ & $<0.001^{*}$ \\
\hline $\begin{array}{l}\text { Total cholesterol } \\
\text { (mg/dL) }\end{array}$ & $195.2(38.8)$ & $203.1(38.8)$ & $<0.001^{*}$ \\
\hline $\mathrm{TG}(\mathrm{mg} / \mathrm{dL})$ & $146.2(97.8)$ & $108.6(77.4)$ & $<0.001^{\star}$ \\
\hline HDL-C (mg/dL) & $46.3(12.1)$ & $57.0(13.6)$ & $<0.001^{*}$ \\
\hline TG/HDL-C ratio & $3.54(2.98)$ & $2.17(2.18)$ & $<0.001^{*}$ \\
\hline ALT (U/L) & $36.4(36.3)$ & $26.4(36.7)$ & $<0.001^{*}$ \\
\hline Anti-HCV (+), n (\%) & $66(8.5)$ & $45(9.2)$ & 0.672 \\
\hline Body fat $\%$ & $24.7(5.2)$ & $30.2(5.2)$ & $<0.001^{*}$ \\
\hline Fat-free mass (kg) & $54.0(6.4)$ & $40.2(4.5)$ & $<0.001^{\star}$ \\
\hline Muscle mass $(\mathrm{kg})$ & $50.0(6.1)$ & $36.9(4.0)$ & $<0.001^{\star}$ \\
\hline $\begin{array}{l}\text { Visceral fat area } \\
\left(\mathrm{cm}^{2}\right)\end{array}$ & $129.7(40.7)$ & $71.5(35.1)$ & $<0.001^{\star}$ \\
\hline $\begin{array}{l}\text { Visceral obesity, } n \\
\text { (\%) }\end{array}$ & $635(81.7)$ & $88(18.0)$ & $<0.001^{\star}$ \\
\hline
\end{tabular}

*Indicates $p<0.0026$, which equals $0.05 / 19$ items.

ALT, alanine aminotransferase; BMI, body mass index; DBP, diastolic blood pressure; HCV, hepatitis $\mathrm{C}$ virus; HDL-C, highdensity lipoprotein cholesterol; MAP, mean arterial pressure; SBP, systolic blood pressure; TG, triglyceride.

\section{Factors associated with visceral obesity in the study population}

In univariate logistic regression analyses, all variables, except for TC and HCV, were correlated with the risk of visceral obesity. In multivariable logistic regression analysis, the following covariates were risk factors for visceral obesity: male gender, older age, higher waist to height ratio and lower muscle mass (table 3 ).

\section{Factors associated with visceral obesity in patients with HCV infection}

Univariate logistic regression analyses revealed that waist to height ratio, body fat percentage, fat-free mass/BW and muscle mass/BW were significantly associated with visceral obesity in both the male and female patients with HCV infection. However, older age and higher fasting glucose levels were positively associated with visceral obesity only in the female patients (table 4).
Determinants of visceral obesity in patients with and without HCV infection

Table 5 demonstrates the associations between body composition parameters-body fat percentage, fat-free mass/BW and muscle mass/BW-and visceral obesity stratified by gender and HCV infection. After adjusting for age in these models (model 2), body fat percentage, fat-free mass/BW and muscle mass/BW were found to be independent determinants in patients without HCV infection (all $\mathrm{p}<0.001$ ). However, the trend was not such obvious in patients with HCV infection (model 2), though all statistically significant (all $\mathrm{p}<0.05)$.

\section{DISCUSSION}

In the current study, after adjusting for other confounding factors, body fat percentage, fat-free mass/BW and muscle mass/BW were independent determinants of visceral obesity in patients with or without HCV infection. However, the trend was not such obvious in patients with HCV infection, though still statistically significant. Furthermore, the trend was less significant in men with $\mathrm{HCV}$ infection. This finding might suggest that HCV modulates host lipid metabolism and distribution to some extent. This study elucidated the gender difference. Previous studies have suggested that HCV modulates the lipid metabolism of host cells to promote its replication. HCV infection is also related to increased lipogenesis, reduced secretion and $\beta$-oxidation of lipids. ${ }^{14}$

In our study, the prevalence rate of the positive anti-HCV antibody was $8.8 \%$ in the study population, $8.5 \%$ in men and $9.2 \%$ in women. According to data from the Liver Disease Prevention and Treatment Research Foundation, HCV prevalence in Taiwan has been estimated to be $4.4 \%$ (or 423283 anti-HCV positive carriers) in adults aged more than 20 years. ${ }^{4}$ This study analysed 157720 patients in the period from 1996 to 2005 and found similar infection rates among men and women, increasing prevalence with age and significant geographical variation. The estimated prevalence of the positive anti-HCV antibody was $6.1 \%$ in the region in which our study population resides. Another nationwide community-based survey on hepatitis HCV was performed in seven townships in Taiwan. ${ }^{15}$ The survey identified that the significant risk factors for the positive anti-HCV antibody were blood transfusion $(\mathrm{OR}=8.6)$, medical injection $(\mathrm{OR}=2.4)$ and acupuncture $(\mathrm{OR}=2.4)$. A systemic review estimated that 49.3-64.0 million adults in Asia, Australia and Egypt are anti-HCV positive. ${ }^{16}$ Although most countries have prevalence rates ranging from $1 \%$ to $2 \%$, some countries have relatively high prevalence rates, including Egypt (15\%), Pakistan $(4.7 \%)$ and Taiwan $(4.4 \%)$.

In the current study, men with HCV infection tended to have lower TC and TG levels. A large-scale community study in Taiwan found that HCV viraemia may be associated with lower serum cholesterol and TG levels ${ }^{17}$; however, the gender difference was not identified. Another study found HCV-associated hypolipidaemia 
Table 2 Metabolic risk and body composition according to presence of hepatitis C virus (HCV) infection in men and women

\begin{tabular}{|c|c|c|c|c|c|c|}
\hline & Males $(n=777)$ & & & Females $(n=49$ & & \\
\hline Variable & HCV- $(n=711)$ & $\mathrm{HCV}+(\mathrm{n}=66)$ & $p$ Value & HCV- $(n=445)$ & $\mathrm{HCV}+(\mathrm{n}=45)$ & p Value \\
\hline Age (year) & $54.1(12.2)$ & $60.6(11.1)$ & $<0.001^{*}$ & $53.4(11.4)$ & $59.4(7.3)$ & $<0.001^{*}$ \\
\hline BMI $\left(\mathrm{kg} / \mathrm{m}^{2}\right)$ & $25.3(3.4)$ & $25.0(3.2)$ & 0.524 & $23.2(3.5)$ & $24.5(3.3)$ & 0.021 \\
\hline Waist circumstance $(\mathrm{cm})$ & $87.2(8.9)$ & $87.8(9.2)$ & 0.631 & $76.2(8.6)$ & $79.9(9.8)$ & 0.007 \\
\hline Waist to height ratio & $0.52(0.05)$ & $0.52(0.06)$ & 0.608 & $0.48(0.06)$ & $0.51(0.06)$ & 0.005 \\
\hline SBP (mm Hg) & $128.8(19.4)$ & $129.7(19.2)$ & 0.725 & $122.7(23.0)$ & $127.2(23.4)$ & 0.214 \\
\hline DBP (mm Hg) & $75.0(12.0)$ & $74.0(10.8)$ & 0.516 & $67.4(11.5)$ & $68.9(11.8)$ & 0.399 \\
\hline MAP $(\mathrm{mm} \mathrm{Hg})$ & $92.9(13.5)$ & 92.5 (12.3) & 0.831 & $85.8(14.3)$ & $88.3(14.5)$ & 0.262 \\
\hline Fasting glucose (mg/dL) & $109.1(31.8)$ & $109.5(32.2)$ & 0.925 & $100.5(24.2)$ & $115.5(45.4)$ & $<0.001^{*}$ \\
\hline Total cholesterol (mg/dL) & $196.9(39.0)$ & $177.0(32.5)$ & $<0.001^{*}$ & $204.2(39.2)$ & $192.3(33.7)$ & 0.051 \\
\hline $\mathrm{TG}(\mathrm{mg} / \mathrm{dL})$ & $148.5(100.5)$ & $121.4(55.6)$ & 0.031 & $109.2(79.6)$ & $102.9(50.0)$ & 0.600 \\
\hline $\mathrm{HDL}-\mathrm{C}(\mathrm{mg} / \mathrm{dL})$ & $46.6(12.3)$ & $43.6(9.6)$ & 0.059 & $57.2(13.6)$ & $55.5(13.8)$ & 0.436 \\
\hline TG/HDL-C ratio & $3.59(3.07)$ & $3.05(1.84)$ & 0.163 & $2.18(2.25)$ & $2.09(1.40)$ & 0.804 \\
\hline ALT (U/L) & $34.4(33.4)$ & $57.6(55.1)$ & $<0.001^{*}$ & $24.4(35.9)$ & $45.3(39.5)$ & $<0.001^{*}$ \\
\hline Body fat $\%$ & $24.7(5.2)$ & $24.8(4.9)$ & 0.924 & $30.0(5.2)$ & $31.8(4.7)$ & 0.027 \\
\hline Fat-free mass $(\mathrm{kg})$ & $54.1(6.5)$ & $53.6(6.1)$ & 0.512 & $40.2(4.5)$ & $41.0(4.6)$ & 0.227 \\
\hline Muscle mass (kg) & $50.0(6.1)$ & $49.4(5.6)$ & 0.429 & $36.8(4.0)$ & $37.6(4.2)$ & 0.240 \\
\hline Visceral fat area $\left(\mathrm{cm}^{2}\right)$ & $129.2(40.9)$ & $134.6(38.7)$ & 0.310 & $70.2(34.4)$ & $84.3(39.6)$ & 0.010 \\
\hline Visceral obesity, n (\%) & $576(81.0)$ & $59(89.4)$ & 0.092 & 75 (16.9) & $13(28.9)$ & 0.045 \\
\hline
\end{tabular}

*Indicates $p<0.0028$, which equals $0.05 / 18$ items.

ALT, alanine aminotransferase; BMI, body mass index; DBP, diastolic blood pressure; HDL-C, high-density lipoprotein cholesterol; MAP, mean arterial pressure; SBP, systolic blood pressure; TG, triglyceride.

(lower TC and TG) in women aged $\geq 49$ years and men of all ages ${ }^{18}$ similarly to our study. Another study suggested that HCV also negatively modulates the synthesis of very-low-density lipoprotein. ${ }^{14}$ In vitro experiments with $\beta$-lipoproteins revealed possible competitive inhibition between HCV and low-density lipoprotein (LDL) receptors for binding LDL in indiviuals with HCV infection. ${ }^{19}$ One previous study found a correlation between the apolipoprotein B (apoB) level and HCV viral load; this finding supports that a high apoB level may decrease the infection of liver cells through competition, leading to a decreased HCV viral load; thus, the correlation might implicate an interaction between hepatitis $\mathrm{C}$ and the $\beta$-lipoprotein metabolism. ${ }^{20}$ All these findings indicate the influence of HCV infection on lipid metabolism. In our study, relatively lower lipid profiles, including TC and TG, and borderline lower HDL levels were observed in men with HCV infection. However, the trend was not statistically significant in women with HCV infection. Another study found lower serum lipid profiles, including TC, HDL and LDL levels, in patients with chronic HCV than in uninfected controls. ${ }^{21}$

In this study, waist to height ratio, body fat percentage, fat-free mass/BW and muscle mass/BW were significantly associated with visceral obesity in both male and female patients with HCV infection. However, older age and higher fasting glucose levels were positively associated with visceral obesity only in women. VAT is known to have a high lipolytic rate; thus, large amounts of free fatty acids are generated and delivered to the liver, causing increased hepatic glucose production, hyperinsulinaemia and metabolic syndrome. ${ }^{22}$ By contrast, accumulation of subcutaneous adipose tissue (SAT) is independently associated with a lower risk of mortality and disorders. ${ }^{23}{ }^{24}$ Moreover, SAT may have protective effects. ${ }^{25}$ Recent data suggest that a high VAT:SAT ratio is a unique risk factor beyond absolute fat volumes. ${ }^{26}$ A previous study focused on the relationship between regional abdominal adiposity and insulin resistance in non-diabetic, middle-aged Taiwanese people with varying BMIs. That study suggested that intraperitoneal fat mass (evaluated through CT) is the optimal predictor of insulin resistance. ${ }^{27}$ Another recent systemic review found significant correlations between insulin resistance and most adipose tissue depots or obesity indices. Among these indices, VAT mass showed the strongest correlation with homoeostatic model assessment-insulin resistance, followed by total fat mass, BMI and waist circumference. ${ }^{28}$

Some studies have described a correlation between visceral obesity and age, fasting glucose level, lipid profile, blood pressure and gender. Older age is associated with increased accumulation of visceral fat. This increase is dramatic in women, almost quadrupling between the ages of 25 and 65 years. The increase is similar in men in absolute terms but not proportionately as dramatic. ${ }^{29}$ Age strongly influences the prediction of intra-abdominal 
Table 3 Association between risk factors and visceral obesity in the total study cohort

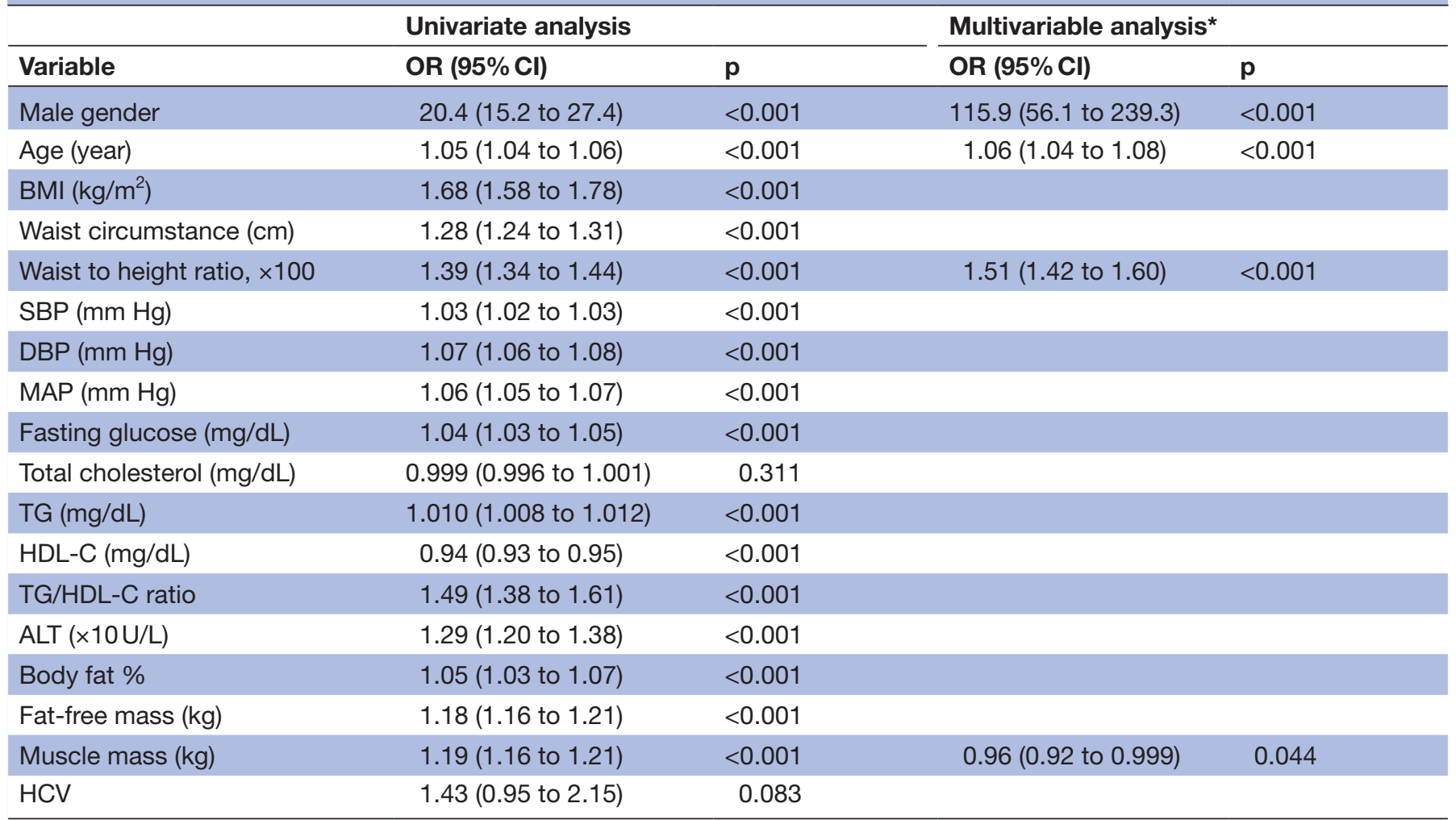

*Backward elimination.

ALT, alanine aminotransferase; BMI, body mass index; DBP, diastolic blood pressure; HCV, hepatitis C virus; HDL-C, high-density lipoprotein cholesterol; MAP, mean arterial pressure; SBP, systolic blood pressure; TG, triglyceride.

adipose tissue from waist circumference. ${ }^{30}$ The VAT area assessed through CT is estimated to increase with age at a rate of $2.36 \mathrm{~cm}^{2}$ per year in healthy non-obese women. ${ }^{31}$ Recent studies have demonstrated that consumption of fructose increases TG and glucose levels, leads to insulin resistance and exacerbates metabolic profile presentation. ${ }^{32} 33$ Consuming fructose is found to increase de novo lipogenesis, dyslipidaemia, visceral adiposity and decrease insulin sensitivity in overweight adults. ${ }^{34}$ Besides, it has long been recognised that the frequency of hypertension in obese persons is significantly higher than that in normal weight and underweight persons. ${ }^{35}$

A previous study reported that women are characterised by lower VAT and higher SAT. ${ }^{36}$ That study also observed a more pronounced increase in VAT in men than in women and in normal weight, overweight and obese individuals. ${ }^{37}$ Regarding sex differences in central obesity, as indicated through CT measurement, the VAT amount is up to twofold higher in men than in premenopausal women. ${ }^{38}$ Moreover, studies have suggested that

Table 4 Factors associated with visceral obesity in patients with HCV infection (univariate logistic regression)

\begin{tabular}{|c|c|c|c|c|}
\hline & Male $(n=66)$ & & Female $(n=45)$ & \\
\hline Variable & OR $(95 \% \mathrm{Cl})$ & $\mathbf{p}$ & OR $(95 \% \mathrm{Cl})$ & $\mathbf{p}$ \\
\hline Age $\geq 60$ years & 0.59 (0.12 to 2.88$)$ & 0.515 & $6.36(1.45 \text { to } 28.02)^{\star}$ & 0.014 \\
\hline Hypertension & 2.63 (0.30 to 23.50$)$ & 0.386 & 2.57 (0.67 to 9.94) & 0.171 \\
\hline Waist to height ratio, $\times 100$ & $1.70(1.18 \text { to } 2.45)^{\star \star}$ & 0.004 & $1.43(1.16 \text { to } 1.77)^{\star \star}$ & 0.001 \\
\hline Fasting glucose (mg/dL) & 1.04 (0.97 to 1.12$)$ & 0.260 & $1.02(1.00 \text { to } 1.04)^{\star}$ & 0.049 \\
\hline TG/HDL-C ratio & 2.17 (0.99 to 4.78 ) & 0.054 & 1.26 (0.81 to 1.96$)$ & 0.313 \\
\hline ALT (×10U/L) & 1.04 (0.87 to 1.25$)$ & 0.661 & 1.18 (0.99 to 1.40$)$ & 0.062 \\
\hline Body fat per cent & $1.75(1.18 \text { to } 2.60)^{\star \star}$ & 0.005 & $1.94(1.30 \text { to } 2.91)^{\star \star}$ & 0.001 \\
\hline Fat-free mass/BW, $\times 100$ & $0.61(0.45 \text { to } 0.84)^{\star *}$ & 0.003 & $0.51(0.34 \text { to } 0.75)^{\star \star \star}$ & $<0.001$ \\
\hline Muscle mass/BW, $\times 100$ & $0.60(0.43 \text { to } 0.84)^{\star \star}$ & 0.003 & $0.50(0.34 \text { to } 0.75)^{\star \star \star}$ & $<0.001$ \\
\hline
\end{tabular}

${ }^{*} \mathrm{p}<0.05 ;{ }^{* *} \mathrm{p}<0.01 ;{ }^{* *} \mathrm{p}<0.001$.

ALT, alanine aminotransferase; BW, body weight; HCV, hepatitis C virus; HDL-C, high-density lipoprotein cholesterol; TG, triglyceride. 
Table 5 Determinants of visceral obesity in patients with and without hepatitis $\mathrm{C}$ virus ( $\mathrm{HCV}$ ) infection

\section{OR $(95 \% \mathrm{Cl})$, per unit increase of parameter}

\begin{tabular}{|c|c|c|}
\hline Subgroup/gender/parameter & Model 1 & Model 2 \\
\hline \multicolumn{3}{|l|}{ Patients with HCV infection } \\
\hline \multicolumn{3}{|l|}{ Men $(n=66)$} \\
\hline Body fat per cent & $1.75(1.18 \text { to } 2.60)^{\star \star}$ & $6.11(1.12 \text { to } 33.36)^{*}$ \\
\hline Fat-free mass/BW, $\times 100$ & $0.61(0.45 \text { to } 0.84)^{\star \star}$ & $0.38(0.18 \text { to } 0.82)^{\star}$ \\
\hline Muscle mass/BW, $\times 100$ & $0.60(0.43 \text { to } 0.84)^{* *}$ & $0.36(0.16 \text { to } 0.81)^{*}$ \\
\hline \multicolumn{3}{|l|}{ Women $(n=45)$} \\
\hline Body fat per cent & $1.94(1.30 \text { to } 2.91)^{\star \star}$ & $1.98(1.29 \text { to } 3.04)^{\star *}$ \\
\hline Fat-free mass/BW, $\times 100$ & $0.51(0.34 \text { to } 0.75)^{\star *}$ & $0.48(0.30 \text { to } 0.76)^{* *}$ \\
\hline Muscle mass/BW, ×100 & $0.50(0.34 \text { to } 0.75)^{\star \star}$ & $0.47(0.30 \text { to } 0.75)^{\star \star}$ \\
\hline \multicolumn{3}{|l|}{ Patients without HCV infection } \\
\hline \multicolumn{3}{|l|}{$\operatorname{Men}(n=711)$} \\
\hline Body fat per cent & $1.78(1.61 \text { to } 1.96)^{\star \star \star}$ & $2.46(2.04 \text { to } 2.97)^{\star \star \star}$ \\
\hline Fat-free mass/BW, $\times 100$ & $0.58(0.53 \text { to } 0.64)^{\star \star \star}$ & $0.43(0.36 \text { to } 0.52)^{\star \star \star}$ \\
\hline Muscle mass/BW, ×100 & $0.58(0.53 \text { to } 0.64)^{\star \star \star}$ & $0.43(0.36 \text { to } 0.51)^{\star \star \star}$ \\
\hline \multicolumn{3}{|l|}{ Women $(n=445)$} \\
\hline Body fat per cent & $2.17(1.81 \text { to } 2.61)^{\star \star \star}$ & $2.16(1.78 \text { to } 2.61)^{\star \star \star \star}$ \\
\hline Fat-free mass/BW, $\times 100$ & $0.49(0.42 \text { to } 0.58)^{\star \star \star}$ & $0.49(0.41 \text { to } 0.59)^{\star * *}$ \\
\hline Muscle mass/BW, ×100 & $0.49(0.41 \text { to } 0.58)^{\star \star \star}$ & $0.48(0.40 \text { to } 0.58)^{\star \star \star}$ \\
\hline
\end{tabular}

Model definitions are: Model 1, unadjusted analysis; Model 2, adjusted for age.

${ }^{*} \mathrm{p}<0.05 ;{ }^{* *} \mathrm{p}<0.01 ;{ }^{* * *} \mathrm{p}<0.001$.

BW, body weight.

VAT deposition increases with age in postmenopausal women, who have about twofold higher extent than in premenopausal women. ${ }^{11}$

In this study, body fat percentage, fat-free mass/BW and muscle mass/BW were independent determinants of visceral obesity in patients without HCV infection. However, the trend was not such obvious in patients with HCV infection, though still statistically significant. Furthermore, the trend was less significant in men with $\mathrm{HCV}$ infection. A previous study discussed sexual dimorphic metabolic alterations in patients with HCV infection and discovered that HCV infection was associated with higher BMI; increased rates of cardiovascular events, diabetes and renal diseases; and a lower rate of hypertension in women, but not in men. ${ }^{18}$

Due to the cross-sectional design and the inclusion of a general population that had undergone a routine health examination, this study had some limitations. First, the sample size was relatively small; thus, the study population could not be divided into different age groups. The small size of the sample with the positive anti-HCV antibody also have influenced the statistical outcome. Therefore, we could only take the current study as a pilot study to find out the trend of current results. Collecting a larger sample size in the future study would be helpful for proving the trend we observed. Second, we evaluated the extent of visceral obesity by using BIA, with body composition analysis, rather than using abdominal CT. Based on our understanding, CT is the gold standard for assessing the visceral fat area. However, because data were collected during health examinations of a relatively healthy population, it was not easy to include CT as one of the routine examination tools due to its associated cost. Therefore, we adopted BIA as a relatively suitable tool to estimate the extent of VAT. Although a recent study cross-validated the regression equation and obtained a strong correlation between BIA and CT for estimating the visceral fat area, ${ }^{13}$ additional studies should confirm the trend in our study by estimating the visceral fat area by using CT. Third, because this cross-sectional study was retrospective, we did not have data on HCV RNA, antiviral treatment status and HCV genotype, which may result in overestimation of and a lack of risk factors for lipid metabolism. However, based on our understanding, among the major genotypes, HCV genotype 1 is the most prevalent worldwide. In Taiwan, HCV subtypes $1 \mathrm{~b}$ and $2 \mathrm{a}$ are the major subtypes. ${ }^{39}$ Future studies collecting a larger sample size with sufficient virological variables and CT-determined visceral fat area may confirm the trend identified in the current study.

The current study result suggested that HCV modulates host lipid metabolism and distribution to some extent, and a trend of gender difference was also noted. Future study might focus on collecting a larger sample size to prove the trend and improve the generalisability. The findings of the current study implicated that for those with positive anti-HCV results, especially male subjects, 
in addition to modifying body composition, clinicians should emphasise improving the parameters of metabolic syndrome to improve the condition of visceral obesity.

Contributors $\mathrm{Y}-\mathrm{CT}$ and $\mathrm{J}-\mathrm{YC}$ were involved in writing of the manuscript. W-CL conceived of and supervised the study. W-CY provided statistical advice. Y-CT and Y-SP collected the data. Y-CT and W-CL conceived, designed and performed the experiments; analysed the data; revised the manuscript critically for important intellectual content; and finally approved the version to be submitted.

Competing interests None declared.

Ethics approval This study protocol was approved by the institutional review board of Chang Gung Medical Foundation (104-8022B).

Provenance and peer review Not commissioned; externally peer reviewed. Data sharing statement No additional data are available.

Open Access This is an Open Access article distributed in accordance with the Creative Commons Attribution Non Commercial (CC BY-NC 4.0) license, which permits others to distribute, remix, adapt, build upon this work non-commercially, and license their derivative works on different terms, provided the original work is properly cited and the use is non-commercial. See: http://creativecommons.org/ licenses/by-nc/4.0/

(c) Article author(s) (or their employer(s) unless otherwise stated in the text of the article) 2017. All rights reserved. No commercial use is permitted unless otherwise expressly granted.

\section{REFERENCES}

1. Mohd Hanafiah K, Groeger J, Flaxman AD, et al. Global epidemiology of hepatitis $C$ virus infection: new estimates of age-specific antibody to HCV seroprevalence. Hepatology 2013;57:1333-42.

2. Shepard CW, Finelli L, Alter MJ. Global epidemiology of hepatitis $C$ virus infection. Lancet Infect Dis 2005;5:558-67.

3. Negro F, Sanyal AJ. Hepatitis C virus, steatosis and lipid abnormalities: clinical and pathogenic data. Liver Int 2009;29(Suppl 2):26-37.

4. Chen $\mathrm{CH}$, Yang PM, Huang GT, et al. Estimation of seroprevalence of hepatitis $B$ virus and hepatitis $C$ virus in Taiwan from a large-scale survey of free hepatitis screening participants. J Formos Med Assoc 2007; 106:148-55.

5. Ramesh S, Sanyal AJ. Hepatitis C and nonalcoholic fatty liver disease. Semin Liver Dis 2004;24:399-413.

6. Yoneda M, Saito $\mathrm{S}$, Ikeda T, et al. Hepatitis $\mathrm{C}$ virus directly associates with insulin resistance independent of the visceral fat area in nonobese and nondiabetic patients. J Viral Hepat 2007;14:600-7.

7. Moucari R, Asselah T, Cazals-Hatem D, et al. Insulin resistance in chronic hepatitis C: association with genotypes 1 and 4 , serum HCV RNA level, and liver fibrosis. Gastroenterology 2008;134:416-23.

8. Del Campo JA, Romero-Gómez M. Steatosis and insulin resistance in hepatitis C: a way out for the virus? World J Gastroenterol 2009;15:5014-9.

9. Adinolfi LE, Gambardella M, Andreana A, et al. Steatosis accelerates the progression of liver damage of chronic hepatitis $C$ patients and correlates with specific HCV genotype and visceral obesity. Hepatology 2001;33:1358-64.

10. Eguchi $Y$, Mizuta T, Ishibashi E, et al. Hepatitis $C$ virus infection enhances insulin resistance induced by visceral fat accumulation. Liver Int 2009;29:213-20.

11. Tchernof A, Després JP. Pathophysiology of human visceral obesity: an update. Physiol Rev 2013;93:359-404.

12. Examination Committee of Criteria for 'Obesity Disease' in Japan, Japan Society for the Study of Obesity. New criteria for 'obesity disease' in Japan. Circ J 2002;66:987-92.

13. Nagai M, Komiya $\mathrm{H}$, Mori $\mathrm{Y}$, et al. Estimating visceral fat area by multifrequency bioelectrical impedance. Diabetes Care 2010;33:1077-9.

14. Syed GH, Amako Y, Siddiqui A. Hepatitis $C$ virus hijacks host lipid metabolism. Trends Endocrinol Metab 2010;21:33-40.

15. Sun CA, Chen HC, Lu CF, et al. Transmission of hepatitis $C$ virus in Taiwan: prevalence and risk factors based on a nationwide survey. J Med Virol 1999;59:290-6.
16. Sievert W, Altraif I, Razavi HA, et al. A systematic review of hepatitis $C$ virus epidemiology in Asia, Australia and Egypt. Liver Int 2011;31:61-80.

17. Dai CY, Chuang WL, Ho CK, et al. Associations between hepatitis C viremia and low serum triglyceride and cholesterol levels: a community-based study. J Hepatol 2008;49:9-16.

18. Hu JH, Chen MY, Yeh CT, et al. Sexual dimorphic metabolic alterations in hepatitis $C$ virus-infected patients: a community-based study in a hepatitis $\mathrm{B} /$ hepatitis $\mathrm{C}$ virus hyperendemic area. Medicine 2016;95:e3546.

19. Monazahian M, Kippenberger S, Müller A, et al. Binding of human lipoproteins (low, very low, high density lipoproteins) to recombinant envelope proteins of hepatitis C virus. Med Microbiol Immunol 2000;188:177-84.

20. Petit JM, Benichou M, Duvillard L, et al. Hepatitis C virusassociated hypobetalipoproteinemia is correlated with plasma viral load, steatosis, and liver fibrosis. Am J Gastroenterol 2003;98:1150-4.

21. Siagris D, Christofidou M, Theocharis GJ, et al. Serum lipid pattern in chronic hepatitis C: histological and virological correlations. J Viral Hepat 2006;13:56-61.

22. Shulman Gl. Ectopic fat in insulin resistance, dyslipidemia, and cardiometabolic disease. N Engl J Med 2014;371:1131-41.

23. Tankó LB, Bagger YZ, Alexandersen P, et al. Central and peripheral fat mass have contrasting effect on the progression of aortic calcification in postmenopausal women. Eur Heart $J$ 2003;24:1531-7.

24. Van Pelt RE, Evans EM, Schechtman KB, et al. Contributions of total and regional fat mass to risk for cardiovascular disease in older women. Am J Physiol Endocrinol Metab 2002;282:E1023-8.

25. Porter SA, Massaro JM, Hoffmann U, et al. Abdominal subcutaneous adipose tissue: a protective fat depot? Diabetes Care 2009;32:1068-75.

26. Kaess BM, Pedley A, Massaro JM, et al. The ratio of visceral to subcutaneous fat, a metric of body fat distribution, is a unique correlate of cardiometabolic risk. Diabetologia 2012;55:2622-30.

27. Hsieh CJ, Wang PW, Chen TY. The relationship between regional abdominal fat distribution and both insulin resistance and subclinical chronic inflammation in non-diabetic adults. Diabetol Metab Syndr 2014;6:49.

28. Zhang M, Hu T, Zhang S, et al. Associations of different adipose tissue depots with insulin resistance: a systematic review and metaanalysis of observational studies. Sci Rep 2015;5:18495.

29. Hunter GR, Gower BA, Kane BL. Age related shift in visceral fat. Int J Body Compos Res 2010;8:103-8.

30. Han TS, McNeill G, Seidell JC, et al. Predicting intra-abdominal fatness from anthropometric measures: the influence of stature. Int J Obes Relat Metab Disord 1997;21:587-93.

31. DeNino WF, Tchernof A, Dionne IJ, et al. Contribution of abdominal adiposity to age-related differences in insulin sensitivity and plasma lipids in healthy nonobese women. Diabetes Care 2001;24:925-32.

32. Tappy L, Lê KA. Metabolic effects of fructose and the worldwide increase in obesity. Physiol Rev 2010;90:23-46.

33. Teff KL, Grudziak J, Townsend RR, et al. Endocrine and metabolic effects of consuming fructose- and glucose-sweetened beverages with meals in obese men and women: influence of insulin resistance on plasma triglyceride responses. J Clin Endocrinol Metab 2009;94:1562-9.

34. Stanhope KL, Schwarz JM, Keim NL, et al. Consuming fructosesweetened, not glucose-sweetened, beverages increases visceral adiposity and lipids and decreases insulin sensitivity in overweight/ obese humans. J Clin Invest 2009;119:1322-34.

35. Stamler R, Stamler J, Riedlinger WF, et al. Weight and blood pressure. Findings in hypertension screening of 1 million Americans. JAMA 1978;240:1607-10.

36. Machann J, Thamer C, Schnoedt B, et al. Age and gender related effects on adipose tissue compartments of subjects with increased risk for type 2 diabetes: a whole body MRI/MRS study. MAGMA 2005; 18:128-37.

37. Bouchard C, Després JP, Mauriège P. Genetic and nongenetic determinants of regional fat distribution. Endocr Rev 1993;14:72-93.

38. Kvist $\mathrm{H}$, Chowdhury B, Grangård U, et al. Total and visceral adipose-tissue volumes derived from measurements with computed tomography in adult men and women: predictive equations. Am J Clin Nutr 1988;48:1351-61.

39. Kao JH. Hepatitis C virus infection in Taiwan: past, present, and future. J Formos Med Assoc 2016;115:65-6. 